\title{
IOWA-MINNESOTA TOWNSITE TOWNS
}

\section{By REMLEY J. GLass}

When W. E. Brice and his associates constructed the Iowa \& Minnesota railway, now the Chicago \& Northwestern railroad, across Cerro Gordo county in 18981899, a part of the division from Belle Plaine, Iowa, to Blue Earth, Minnesota, the Iowa \& Minnesota Townsite company platted a number of small towns-Wheelerwood, Hanford, Cartersville and Dougherty-along the right of way in that county.

Early settlers will recall that the surveyor for all these communities was C. T. Dike, later vice president of the Chicago \& Northwestern railroad, and now, after his retirement, once more a citizen of Mason City, Iowa. His name was given to the town of Dike in Grundy county on the Northwestern line, which he helped to construct.

WHEELERWOOD-Wheelerwood, located in the northwest quarter section of 11-97-21 in Lincoln township, then a part of the J. S. Wheeler stock farm, was platted on November 21, 1899. It was named for J. S. Wheeler, a pioneer stock raiser, capitalist and banker of the community. All the street names in Wheelerwood-Wiltsie, Wheeler, Webb and the rest of them-save Main street, began with the letter "W." A post office was established in 1900 and store buildings and homes were constructed. Changing economic and social conditions caused the elimination of this little community and now all the lots in Wheelerwood save one are in the name of the owners of the Wheeler ranch, while only one building, the old store with the Woodman hall above it, remains.

HANFORD-Down along the western edge of Owen township, a few miles southeast of Mason City, the 
Iowa-Minnesota Townsite company platted Hanford on July 16, 1900. It was named for the Hanford family prominent in early days. Mrs. C. H. MacNider was a member of that family and gave her maiden name to her son Brig. Gen. Hanford MacNider. Stores, shops, homes and a post office were erected there, but today the ambitious dreams of its citizens have vanished and only a few residences, a shop or two, and a little church remain.

Cartersville-Midway on the border line between Owen and Dougherty townships in sections 4-94-19 and 33-95-19 the little town of Cartersville was platted on July 16, 1900. It was named for J. S. Carter, an early resident of Mason City. The ambitious plans of its founders resulted in a prosperous community with banks, stores, a Catholic church and a considerable population. The economic struggle of 1920-1930 saw its bank fail and a gradual diminution of its population. Its citizens are loyal to it however and the Cartersville Irish picnic, held each summer, is one of the traditional celebrations of the county.

DougherTY-Back in the fifties Daniel Dougherty and his family. had settled in Clayton county in northeast Iowa, but a little later came farther west to establish themselves in the southeast corner of Cerro Gordo county, where he was one of the large land owners. Dougherty township was named for the family and when the railroad came it was fitting that the town likewise should bear that name. It was platted on July 2, 1900, on parts of sections 25 and 36-94-19 not far from where Cold Water post office had been located in earlier years. It is a prosperous little village with a beautiful Catholic church just across the street from the old Dougherty homestead. 
Copyright of Annals of Iowa is the property of State of Iowa, by \& through the State Historical Society of Iowa and its content may not be copied or emailed to multiple sites or posted to a listserv without the copyright holder's express written permission. However, users may print, download, or email articles for individual use. 